\title{
Higher agrobiodiversity is associated with improved dietary diversity, but not child anthropometric status, of Mayan Achí people of Guatemala
}

\author{
Diana V Luna-González* $\uparrow$ and Marten Sørensen \\ Department of Plant and Environmental Sciences, Faculty of Science, University of Copenhagen, Thorvaldsensvej 40, \\ Frederiksberg 1871, Denmark
}

Submitted 19 March 2017: Final revision received 20 January 2018: Accepted 15 February 2018: First published online 3 April 2018

\begin{abstract}
Objective: Child undernutrition remains one of the greatest challenges for public health nutrition in rural areas in developing countries. Interventions aiming to increase and conserve agrobiodiversity seem to be promising alternatives to improve child nutrition. However, the existing literature on these interventions is not conclusive about their effectiveness in combating child undernutrition. We tested the hypothesis that 'higher agrobiodiversity is associated with greater dietary diversity and better anthropometric status' in rural Guatemala.

Design/Setting/Subjects: In the summer of 2016, we conducted a cross-sectional study with a sample of 154 children (6-60 months). We conducted dietary recalls and structured interviews, measured children's weight and height, and visited food production systems (Milpas, home gardens, coffee plantations). Crop species richness, nutritional functional diversity, dietary diversity scores and anthropometric status were calculated.

Results: Higher food self-sufficiency, nutritional functional diversity and dietary diversity scores were positively correlated with higher crop and animal species richness. Contrarily, remoteness to the local market was negatively correlated with dietary diversity scores. However, higher dietary diversity scores were not correlated with better child anthropometric status. Better child anthropometric status was positively correlated with improved sanitary conditions and maternal education; and negatively correlated with large household size and frequent child morbidity.

Conclusions: Agricultural diversification could diversify diets, increase nutrient availability and improve child anthropometry. However, these interventions need to be accompanied by sanitation improvements, family planning, nutritional education and women's empowerment to strengthen their positive effect on diet and nutrition.
\end{abstract}

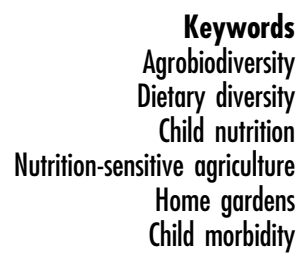

Child undernutrition remains one of the greatest challenges for public health nutrition in rural areas in developing countries. Stunting, which affects one out of four of the world's children under 5 years old ${ }^{(1)}$, is about 1.5 times higher in rural areas than in urban areas ${ }^{(2)}$. In Guatemala, $46 \%$ of children under 5 years are stunted, but it can reach up to $70 \%$ in the poorest rural regions ${ }^{(3)}$. Agricultural interventions have been a common approach to improve food security ${ }^{(4,5)}$ and, consequently, child nutrition. However, some of these interventions have had detrimental effects on the environment and human health ${ }^{(6,7)}$.

$\dagger$ Present address: School of Environment, Resources and Sustainability, Faculty of Environment, University of Waterloo, 200 University Avenue West, Waterloo, Ontario, Canada, N2L 3G1.
Their intensive use of natural resources and chemical inputs have polluted, degraded and disturbed terrestrial ecosystems, reducing their resilience and sustainability. Also, their narrow focus on a limited range of starchy crops (e.g. wheat, rice, maize $)^{(8-10)}$ might have contributed to decreased agrobiodiversity ${ }^{(11,12)}$ and increased micronutrient deficiencies ${ }^{(13,14)}$. Consequently, there is an urgent need for environmentally sustainable, nutrition-sensitive alternatives to these agricultural interventions.

In this regard, interventions focused on conservation and sustainable use of agrobiodiversity $\ddagger$ seem to be promising

$\ddagger$ In the present paper, we use the FAO's definition of 'agrobiodiversity', which comprises the variety of domesticated and wild plants and animals that is used for food and that supports agroecosystems ${ }^{(110)}$. 


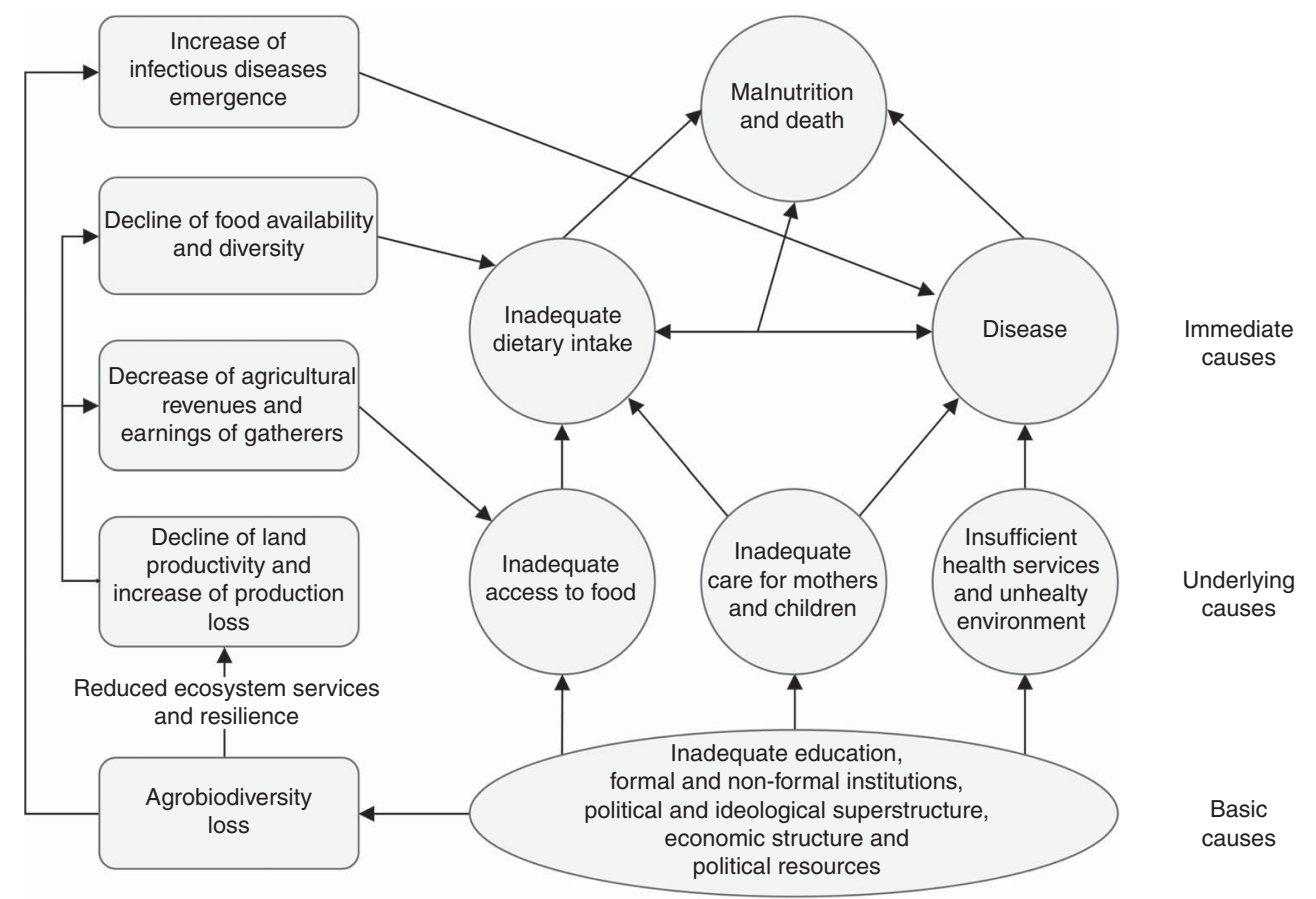

Fig. 1 Hypothetical relationship between agrobiodiversity degradation and causes of undernutrition (adapted from UNICEF ${ }^{(106)}$ )

alternatives to sustainably improve child nutrition ${ }^{(15-18)}$. These interventions account for diversified farming systems ${ }^{(19)}$; homestead food production, such as home gardens and small animal husbandry ${ }^{(20)}$; and conservation, utilization and marketing of neglected, underutilized species, ${ }^{*}$ such as wild edible plants ${ }^{(21,22)} \dagger$ Nutrition is expected to be affected by these interventions through three main pathways (Fig. 1): (i) increasing availability of and accessibility to food types and dietary nutrients ${ }^{(23,24)}$; (ii) strengthening ecosystem functions and providing ecosystem services that could enhance the sustainability of farming systems ${ }^{(25,26)}$; and (iii) conserving genetic resources in situ/on-farm to enhance crops' nutritional content ${ }^{(27)}$ or adaptability to climate change ${ }^{(28,29)}$. But, although the pathways are clear, the existing literature on these interventions is not conclusive about their effectiveness in combating child undernutrition ${ }^{(30-33)}$.

Studies on the association among agrobiodiversity, diet and nutrition have delivered inconsistent results. Some scholars showed that cultivated agrobiodiversity can enhance food self-sufficiency ${ }^{(34-36)}$ and food security ${ }^{(37-39)}$, diversify diets and nutrient intakes ${ }^{(35,37,38,40-52)}$ and increase agricultural revenues to purchase food ${ }^{(41,42,48,53,54)}$. However, other scholars found that it can negatively affect

* Species are denominated 'neglected and underutilized species' when the entire species or an edible part of it occupies low levels of utilization. For example, participants of the present study cultivated cassava, but they did not eat the leaves even though they are edible.

$\dagger$ 'Wild' does not mean the 'absence of human management as the plants can be cultivated, protected, tolerated or promoted without necessarily becoming a domesticated species'. Wild edible plants only means that plants are independent of human intervention for survival ${ }^{(111)}$. nutrition; cultivated agrobiodiversity can limit the available time for child care and feeding ${ }^{(55,56)}$, offer lower yields and revenues than specialized agriculture ${ }^{(53)}$ and increase child morbidity due to livestock ownership ${ }^{(57)}$. Moreover, evidence on wild agrobiodiversity showed that wild edible plants barely contributed to the daily nutrient requirements of farmers ${ }^{(58-60)}$ (except for subsistence farmers ${ }^{(52)}$ ) despite wild edible plants' high micronutrient content ${ }^{(52,61,62)}$. In addition, the majority of the studies were carried out in Africa and $\mathrm{Asia}^{(30)}$, neglecting America. Therefore, no conclusion could be drawn with respect to the effect of agrobiodiversity on nutrition from the existing studies. These inconsistencies expound the complexity of the association among agrobiodiversity, diet and nutrition ${ }^{(63)}$ and call for a systematic, transdisciplinary approach ${ }^{(64)}$.

We explored the relationship among agrobiodiversity, diet and nutrition using a food system framework and cross-disciplinary approach. We attempted to explore this relationship in Latin America, a neglected region in this subject of interest, combining methods from ethnobotany, ecology and nutritional science. Our framework correlates agrobiodiversity and child nutrition through dietary diversity, and explores the exogenous factors influencing the relationship, such as socio-economic status, ethnicity, agricultural extension services, maternal education and age, market distance, and land and livestock ownership (see Fig. 4). We hypothesized that higher agrobiodiversity is associated with a more diversified diet and better anthropometric status in rural Guatemala. This framework, although it does not attempt to be exclusive or complete, can be useful to systematically study this relationship in rural 
areas and evaluate nutrition-sensitive agricultural interventions.

\section{Methods}

\section{Location and population}

The study took place in a rural municipality in the department of Baja Verapaz in Guatemala. This municipality is characterized by a large Indigenous population of the Mayan Achí ethnic group, extensive traditional ecological knowledge ${ }^{(65)}$, wide practice of subsistence agriculture and high rates of child undernutrition and poverty. The mean annual temperature is $22.39^{\circ} \mathrm{C}$ with a mean annual precipitation of $769 \mathrm{~mm}$. Two seasons are reported by informants: a dry season, starting in November, when maize (Zea mays L.) is harvested; and a rainy season, beginning in May, when maize is planted.

Six villages in the highlands of the municipality were selected after considering ecological and geographical characteristics to ensure that the range of edible species produced in the villages does not vary. Altitude ranged between 1300 and $1800 \mathrm{~m}$ above sea level and supported subtropical wet and moist forest ${ }^{(66)}$ on entisols and inceptisols according to US Department of Agriculture soil taxonomy $^{(67)}$. In addition, the villages were located at increasing distance from the main market to test the association between remoteness to the market and dietary diversity ${ }^{(43)}$.

The sample was composed of 154 randomly selected children aged 6-60 months and their 127 caregivers (e.g. mother, grandmother, aunt, sister), whom we refer to as 'mothers' in the present paper (Table 1). We used a sample size calculator ${ }^{(68)}$ with a confidence level of $95 \%$, a total population size $(n)$ of 260 children aged 6-60 months, a CI of 5\% and a population proportion of stunted children of $60 \%{ }^{(69)}$. Households were selected by convenience sampling due to the lack of demographic and cartographic data to randomize participants. Households with children were identified by a snowball sampling technique: asking people where children between 6 and 60 months of age lived.

Between March and July of 2016, face-to-face structured interviews were conducted to gather demographic and socio-economic information. The topics addressed were the following: demographic characteristics of the household (e.g. number of persons, level of education, age), agricultural practices (e.g. number of plots, edible species cultivated, agricultural inputs) and socio-economic information (e.g. housing conditions, assets ownership, sanitary conditions, income-generating activities). The last category helped to calculate the socio-economic status according to the method used by the Institute of Nutrition of Central America and Panama ${ }^{(70,71)}$. This method includes the following variables in the calculation: housing conditions, number of household members, economic activity of household head, assets ownership, and water, sanitation and hygiene (WASH).

We collaborated with a local non-governmental association* who approved our research and facilitated our access to the participants and local authorities. This association provides agricultural extension services and conducts nutrition-sensitive interventions based on the conservation of traditional ecological knowledge, utilization of native wild edible plants, and sustainable use of agrobiodiversity on home gardens and Milpas. $\dagger$ In addition, the study followed the International Society of Ethnobiology Code of Ethics to work with Indigenous people and biocultural diversity (traditional knowledge, biodiversity and cultural diversity $)^{(72)}$. The objectives and procedures of the study were explained to all mothers and they provided verbal informed consent before the interview. We conducted the interviews in Spanish; no interpreter was needed.

\section{Agrobiodiversity assessment}

The crops cultivated by the participants were listed and identified to assess the agrobiodiversity status of the food systems $\ddagger$ During the interviews, the mothers recalled the crops cultivated for food, but edible plants used solely for medicinal purposes were omitted from the data organization. Then, during the visit to the participant's food systems (i.e. home gardens, Milpas, coffee plantations, tomato nurseries), we extended the list of cultivated crops, and we took plant pictures and specimens with the mothers' permission. Specimens were identified in collaboration with the herbarium staff at the University of San Carlos of Guatemala using dichotomous keys from the 'Flora of Guatemala',(73) and corroborating the latest accepted scientific names in The Plant List ${ }^{(74)}$. The correct taxonomic identification of species was essential to the present study because we calculated the nutritional functional diversity based on the features of each plant.

Three indicators of agrobiodiversity richness were calculated with the data gathered: (i) 'crop species richness' was determined by the number of edible crop species, both cultivated and wild, found in the participants' food systems; (ii) 'livestock ownership' was measured as the number of domestic animals bred for food by participants; and (iii) the 'nutritional functional diversity' (NFD) metric ${ }^{(75)}$ was used to quantify the functions (i.e. dietary nutrients) provided to diet by the agrobiodiversity found in the participants' food systems $^{(23,75,76)}$. The NFD metric was used as a proxy of nutritional diversity of the food systems. For instance,

\footnotetext{
* The names of the organization and villages have been deleted to preserve the anonymity of the participants.

† Milpa is a traditional system practised in Mesoamerica: intercropping of maize with beans, squash and other complementary crops, such as darkgreen leafy vegetables (see Table 2 ).

$\ddagger$ In the present paper, we use the term 'food system' to refer to any system where food can be produced, gathered or purchased, such as a farm, forest or market.
} 


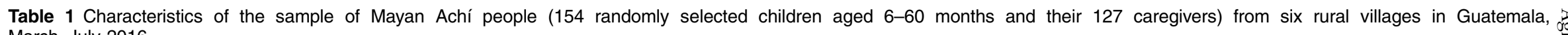
March-July 2016

\begin{tabular}{|c|c|c|c|c|c|c|c|c|c|c|c|c|c|c|}
\hline \multirow[b]{2}{*}{ Characteristic } & \multicolumn{2}{|c|}{ Village A } & \multicolumn{2}{|c|}{ Village B } & \multicolumn{2}{|c|}{ Village C } & \multicolumn{2}{|c|}{ Village D } & \multicolumn{2}{|c|}{ Village $\mathrm{E}$} & \multicolumn{2}{|c|}{ Village $\mathrm{F}$} & \multicolumn{2}{|l|}{ Total } \\
\hline & $\begin{array}{l}\text { Median or } \\
\text { Mean }\end{array}$ & $\begin{array}{l}\text { IQR or } \\
\text { SD }\end{array}$ & $\begin{array}{l}\text { Median or } \\
\text { Mean }\end{array}$ & $\begin{array}{l}\text { IQR or } \\
\text { SD }\end{array}$ & $\begin{array}{l}\text { Median or } \\
\text { Mean }\end{array}$ & $\begin{array}{l}\text { IQR or } \\
\text { SD }\end{array}$ & $\begin{array}{l}\text { Median or } \\
\text { Mean }\end{array}$ & $\begin{array}{l}\text { IQR or } \\
\text { SD }\end{array}$ & $\begin{array}{l}\text { Median or } \\
\text { Mean }\end{array}$ & $\begin{array}{l}\text { IQR or } \\
\text { SD }\end{array}$ & $\begin{array}{l}\text { Median or } \\
\text { Mean }\end{array}$ & $\begin{array}{l}\text { IQR or } \\
\text { SD }\end{array}$ & $\begin{array}{l}\text { Median or } \\
\text { Mean }\end{array}$ & $\begin{array}{l}\text { IQR or } \\
\text { SD }\end{array}$ \\
\hline Distance to market $(\mathrm{km})^{*}$ & \multicolumn{2}{|c|}{$6 \cdot 8$} & \multicolumn{2}{|c|}{$8 \cdot 2$} & \multicolumn{2}{|l|}{9.5} & \multicolumn{2}{|c|}{$10 \cdot 2$} & \multicolumn{2}{|c|}{13.4} & \multicolumn{2}{|c|}{$15 \cdot 2$} & \multicolumn{2}{|l|}{ - } \\
\hline Altitude (masl)* & \multirow{2}{*}{\multicolumn{2}{|c|}{$\begin{array}{r}1345 \\
0.1\end{array}$}} & & & & & & & & & \multirow{2}{*}{\multicolumn{2}{|c|}{1805}} & - & \\
\hline Distance to nearest river $(\mathrm{km})^{\star}$ & & & \multicolumn{2}{|l|}{$\begin{array}{r}1400 \\
1.0\end{array}$} & \multicolumn{2}{|l|}{$\begin{array}{c}1610 \\
0.6\end{array}$} & \multicolumn{2}{|c|}{$\begin{array}{r}1580 \\
2 \cdot 6\end{array}$} & \multicolumn{2}{|c|}{$\begin{array}{r}1750 \\
0.8\end{array}$} & & & - & \\
\hline Household characteristics & & & & & & & & & & & & & & \\
\hline No. of households & 21 & & 26 & & 27 & & 13 & & 17 & & 23 & & 127 & \\
\hline No. of household members $\dagger$ & $6 \cdot 0$ & 4.0 & $7 \cdot 0$ & 4.0 & $6 \cdot 0$ & 1.0 & 8.0 & $2 \cdot 0$ & 6.0 & $5 \cdot 0$ & $6 \cdot 0$ & 1.0 & 6.0 & 3.0 \\
\hline No. of children living in home† & 1.0 & 1.0 & $2 \cdot 0$ & 1.0 & $2 \cdot 0$ & 1.0 & $2 \cdot 0$ & 1.0 & $1 \cdot 0$ & 1.0 & $2 \cdot 0$ & 1.0 & $2 \cdot 0$ & 1.0 \\
\hline SES $\ddagger$ & $10 \cdot 2$ & 1.4 & 8.9 & 1.5 & $10 \cdot 1$ & 1.4 & 8.6 & 1.7 & 8.7 & 1.6 & $8 \cdot 1$ & 1.0 & $9 \cdot 2$ & 1.6 \\
\hline Safe sewage disposal (\% yes) & 4.3 & & 0.0 & & 7.4 & & 9.1 & & 11.8 & & 4.3 & & $6 \cdot 0$ & \\
\hline Access to water ( $\%$ yes) & 95.7 & & 88.9 & & $96 \cdot 3$ & & $90 \cdot 9$ & & $70 \cdot 6$ & & $66 \cdot 7$ & & 85.5 & \\
\hline Dirt floor (\% yes) & 56.5 & & $83 \cdot 3$ & & 63.0 & & 45.5 & & 58.8 & & $81 \cdot 0$ & & $65 \cdot 8$ & \\
\hline Access to electricity (\% yes) & $95 \cdot 7$ & & $66 \cdot 7$ & & $74 \cdot 1$ & & $90 \cdot 9$ & & $70 \cdot 6$ & & $19 \cdot 0$ & & $68 \cdot 4$ & \\
\hline Household head employment & & & & & & & & & & & & & & \\
\hline Farmer (\%) & $12 \cdot 0$ & & 24.1 & & $20 \cdot 6$ & & $18 \cdot 8$ & & $57 \cdot 1$ & & $16 \cdot 0$ & & $22 \cdot 4$ & \\
\hline Formal employment (\%) & 48.0 & & 6.9 & & 38.2 & & 18.8 & & $14 \cdot 3$ & & 0.0 & & $22 \cdot 4$ & \\
\hline Informal employment (\%) & 40.0 & & 69.0 & & $41 \cdot 2$ & & 62.5 & & 28.6 & & 84.0 & & $55 \cdot 2$ & \\
\hline Home garden ownership (\% yes) & 76.9 & & $89 \cdot 3$ & & $64 \cdot 7$ & & $88 \cdot 2$ & & $76 \cdot 2$ & & $76 \cdot 0$ & & 77.5 & \\
\hline $\begin{array}{l}\text { Crop species richness in all systems (no. of } \\
\text { edible crop species)t }\end{array}$ & $15 \cdot 0$ & $8 \cdot 0$ & $17 \cdot 0$ & $7 \cdot 0$ & $13 \cdot 5$ & $9 \cdot 0$ & $16 \cdot 0$ & $13 \cdot 0$ & $17 \cdot 0$ & $10 \cdot 0$ & $13 \cdot 0$ & $8 \cdot 0$ & $15 \cdot 0$ & 8.0 \\
\hline $\begin{array}{l}\text { Crop species richness in home gardens } \\
\text { (no. of edible crop species)t }\end{array}$ & $13 \cdot 0$ & $6 \cdot 0$ & $12 \cdot 0$ & $5 \cdot 0$ & $10 \cdot 0$ & $7 \cdot 0$ & $12 \cdot 0$ & $11 \cdot 0$ & $14 \cdot 0$ & $6 \cdot 0$ & $10 \cdot 0$ & $7 \cdot 0$ & $12 \cdot 0$ & $7 \cdot 0$ \\
\hline QA beneficiary (\% yes) & $7 \cdot 7$ & & $96 \cdot 2$ & & $11 \cdot 8$ & & 68.4 & & $85 \cdot 7$ & & $20 \cdot 7$ & & $50 \cdot 4$ & \\
\hline Child characteristics & & & & & & & & & & & & & & \\
\hline No. of children & 26 & & 29 & & 34 & & 19 & & 21 & & 25 & & 154 & \\
\hline No. of children aged $<24$ months & 14 & & 11 & & 13 & & 9 & & 7 & & 4 & & 58 & \\
\hline Age of child (months) $\dagger$ & 23.0 & $15 \cdot 0$ & 33.0 & $32 \cdot 0$ & $28 \cdot 0$ & $30 \cdot 0$ & $30 \cdot 0$ & $31 \cdot 0$ & 28.0 & $27 \cdot 0$ & $35 \cdot 0$ & $18 \cdot 0$ & 29.0 & $26 \cdot 0$ \\
\hline Sex $(\%$ male $)$ & 50.0 & & 27.6 & & 55.9 & & $36 \cdot 8$ & & 52.4 & & 48.0 & & 45.5 & \\
\hline Mayan Achí (\% yes) & $100 \cdot 0$ & & 96.6 & & $82 \cdot 4$ & & $100 \cdot 0$ & & 90.5 & & 32.0 & & 83.12 & \\
\hline Morbidity in the last month (\% yes) & 63.6 & & $100 \cdot 0$ & & 84.6 & & $100 \cdot 0$ & & 38.9 & & $50 \cdot 0$ & & $67 \cdot 1$ & \\
\hline $\begin{array}{l}\text { IYCDDS of children aged }<24 \text { months } \\
\text { (no. of food groups/d) } \dagger\end{array}$ & $4 \cdot 2$ & 1.0 & 4.0 & 1.5 & 4.5 & 1.0 & 4.0 & $2 \cdot 0$ & $5 \cdot 0$ & 1.5 & $5 \cdot 0$ & 0.7 & 4.5 & 1.0 \\
\hline $\begin{array}{l}\text { IDDS of children aged } \geq 24 \text { months } \\
\text { (no. of food groups/d) } \dagger\end{array}$ & 4.0 & 1.0 & 4.0 & 0.6 & 4.0 & $1 \cdot 0$ & $5 \cdot 0$ & $2 \cdot 2$ & $5 \cdot 0$ & 0.5 & 4.5 & 1.0 & $4 \cdot 2$ & 1.0 \\
\hline Stunting (\%) & & & & & & & & & & & & & & \\
\hline Moderate & 26.9 & & 44.8 & & $44 \cdot 1$ & & $42 \cdot 1$ & & 28.6 & & $44 \cdot 0$ & & 39.0 & \\
\hline Severe & 19.2 & & $27 \cdot 6$ & & 8.8 & & 31.6 & & $14 \cdot 3$ & & $32 \cdot 0$ & & 21.4 & \\
\hline Underweight (\%) & & & & & & & & & & & & & & \\
\hline Moderate & 11.5 & & 13.8 & & $17 \cdot 6$ & & $21 \cdot 1$ & & 28.6 & & $24 \cdot 0$ & & $18 \cdot 8$ & \\
\hline Severe & 0.0 & & 3.4 & & 0.0 & & 0.0 & & 0.0 & & 0.0 & & 0.6 & \\
\hline Maternal characteristics & & & & & & & & & & & & & & \\
\hline Primary caregiver education (years) $\dagger$ & $7 \cdot 0$ & $4 \cdot 0$ & 6.0 & $3 \cdot 0$ & 4.0 & 3.0 & 1.0 & 3.0 & $3 \cdot 0$ & $4 \cdot 0$ & 3.0 & $4 \cdot 0$ & 4.0 & $4 \cdot 0$ \\
\hline Primary caregiver literacy (\% no) & $7 \cdot 7$ & & $20 \cdot 7$ & & $15 \cdot 2$ & & $50 \cdot 0$ & & $14 \cdot 3$ & & $25 \cdot 0$ & & 20.5 & \\
\hline Primary caregiver age (years) $\dagger$ & $23 \cdot 0$ & 8.0 & $22 \cdot 0$ & $16 \cdot 0$ & $26 \cdot 0$ & $13 \cdot 0$ & 36.0 & $15 \cdot 0$ & $26 \cdot 0$ & $17 \cdot 0$ & 28.0 & 8.0 & $27 \cdot 0$ & $14 \cdot 0$ \\
\hline
\end{tabular}

QR, interquartile range; masl, metres above sea level; QA, agricultural extension services promoting home gardening and agroecology; SES, socio-economic status; IYCDDS, infant and young child dietary diversity score; IDDS, individual dietary diversity score.

*Characteristics measured at and from the village school (point of reference).

†Data presented as median and IQR.

fData presented as mean and SD. 
systems comprising crops with similar nutritional values (e.g. maize, banana and potato) would have a lower NFD score than systems with the same number of crops but with different nutritional values (e.g. maize, beans and amaranth leaves).

The NFD scores were calculated using the nutritional values of the crops identified in the participants' food systems. The nutrient values were gathered from two food composition databases, those of the Institute of Nutrition of Central America and Panama ${ }^{(77)}$ and the US Department of Agriculture $^{(78)}$, where data are presented per $100 \mathrm{~g}$ edible portion of food. Macronutrients (protein, fat, carbohydrate, fibre), minerals (Ca, P, Fe, $\mathrm{Zn}, \mathrm{Mg}$ ) and vitamins (thiamin, riboflavin, niacin, vitamin $\mathrm{C}$, vitamin $\mathrm{A}$, folate) content of the identified crops were gathered and used for the calculation of the NFD scores. These nutrient content values depended on the part of the crop utilized by the participants (e.g. both amaranth grain and leaves were included), the condition of the crop when consumed (e.g. mango was included twice because it is consumed in its green and ripe form), the preparation of the food (e.g. raw $v$. cooked) and the species variety cultivated (e.g. red, white and black beans). The data were entered as percentage of the RDA of a male adult ${ }^{(79)}$. The NFD scores reported are percentages of the potential NFD, when all the crops available in the municipality are included in one hypothetical parcel.

\section{Child dietary assessment}

The children diets were assessed using $24 \mathrm{~h}$ recalls and by estimating dietary diversity scores. The mothers were asked to recall their child's food intake during the previous two days; if the child's diet of one of those days was atypical (due to festivities or visits to town or friends), another day was recalled. The foods recalled were classified into the sixteen food groups ${ }^{(80)}$ of the Food and Nutrition Technical Assistance Project (Table 2) and, then, the food groups were used to calculate the dietary diversity scores. The infant and young child dietary diversity score (IYCDDS) ${ }^{(81)}$ was calculated for children aged 6-23 months using seven food categories, while the individual dietary diversity score (IDDS) ${ }^{(82)}$ was calculated for children aged 24-60 months using nine food categories (Table 2). Moreover, the mothers were asked whether the foods consumed were self-produced, gathered in the forest or on the shore of the river, purchased, gifted, borrowed or provided as food aid.

\section{Child anthropometric assessment}

Anthropometric measures were conducted to determine the nutritional status of child participants. The weight of all children was measured using a digital scale (Tecnipesa, Guatemala); the length of the children aged 6-23 months and the height of the children aged 24-60 months were measured with a wooden stadiometer. Measurements were taken in collaboration with participating local nutritionists trained in anthropometric assessment. Height/ length-for-age $Z$-score (HAZ), weight-for-age $Z$-score (WAZ) and weight-for-height/length $Z$-score (WHZ) were determined using the WHO Anthro macros ${ }^{(83)}$ in $\mathrm{R}$ version 3.4.2. The children with $\mathrm{HAZ}<-2 \cdot 0$ were categorized as stunted, children with WAZ $<-2 \cdot 0$ were categorized as underweight and children with $\mathrm{WHZ}<-2 \cdot 0$ were categorized as wasted.

\section{Statistical analysis}

Correlations and comparison of groups were run on the collected data. The normality of the data was always checked using graphical and numerical methods. Spearman $\left(r^{\mathrm{s}}\right)$ and Pearson $\left(r^{\mathrm{p}}\right)$ correlations were used to quantify and determine the direction of the association between two variables, such as agrobiodiversity and dietary diversity scores. The $t$ test and Mann-Whitney $U$ test were used to compare two unpaired groups, such as Mayan Achí people and Ladino people (non-Indigenous). All data were analysed using $\mathrm{R}$ version 3.4 .2 and the statistical software package IBM SPSS Statistics version 24.0.

\section{Results}

\section{Agrobiodiversity}

The participants' food systems were rich in agrobiodiversity. Five different systems supplied food to the participants; listed in decreasing order of crop species richness, they are: (i) the market, (ii) home gardens, (iii) Milpas, (iv) forest and river banks, and (v) coffee plantations and tomato nurseries (Fig. 2). These systems collectively contained ninety-two crop species; forty-two species were native to Mesoamerica and twenty-one were wild edible plants. The richest system in cultivated biodiversity, a home garden, contained twenty-eight edible species, the richest Milpa contained six species and the richest coffee plantation contained four species; all the tomato nurseries were monocultures. The ten most commonly cultivated crops were the following: (i) banana (Musa $\times$ paradisiaca L.); (ii) American black nightshade (Solanum americanum Mill.); (iii) peach (Prunus persica (L.) Batsch); (iv) maize (Z. mays L.); (v) coriander (Coriandrum sativum L.); (vi) amaranth (Amaranthus spp.); (vii) radish (Raphanus raphanistrum subsp. sativus (L.) Domin); (viii) coffee (Coffea arabica L.); (ix) orange (Citrus sinensis (L.) Osbeck); and (x) avocado (Persea americana Mill.).

The market was the richest food system in agrobiodiversity. The market was open all week long, but the main market days were Thursday and Sunday. On these days, farmers from different geographic regions took their produce to the market to sell it; thus, consumers could purchase a wide diversity of foods coming from the municipality villages (e.g. coffee from the highlands and tamarind from the lowlands), other regions of Guatemala (e.g. pineapple (Ananas comosus (L.) Merr.) and cantaloupe (Cucumis melo var. cantalupo Ser.)) or other 
Table 2 Classification of crops cultivated in the municipality according to the IYCDDS and IDDS food groups

Food group (FANTA) Food group (IYCCDDS ${ }^{(107)}$ ) Food group $\left(\right.$ IDDS $\left.^{(82)}\right)$ Food and drink items

1. Cereals

Grains, roots and tubers

Starchy staples

Starchy staples

White roots and tubers Grains, roots and tubers

Vitamin-A rich vegetables and tubers

4. Dark-green leafy vegetables

Vitamin A-rich fruits and vegetables

Vitamin A-rich fruits and vegetables

5. Other vegetables

Other fruits and vegetables

Other fruits and

vegetables

Dark green leafy vegetables

Other vitamin A-rich fruits and vegetables

6. Vitamin-A rich fruits Vitamin A-rich fruits and vegetables

7. Other fruits Other fruits and vegetables

Other vitamin A-rich fruits and vegetables

Amaranth [grain] (Amaranthus spp.) ${ }^{\star}$, Maize [dry; red, white, yellow] (Zea mays L.) \{atol, pinol, tamal, tortilla\}, Oats (Avena sativa L.) \{horchata, mosh\}t, Rice (Oryza sativa L.) \{arroz con leche, horchata\}t, Wheat (Triticum aestivum L.) atol, bread, chomin, pasta\}t

Cassava (Manihot esculenta Crantz), Plantains (Musa x paradisiaca L.), Potatoes (Solanum tuberosum L.)t, Sweet potato [red, purple, white] (Ipomoea batatas (L.) Lam.)t, Taro (Colocasia esculenta (L.) Schott)

Carrot (Daucus carota L.), Pumpkin [flower, orange and dark yellow flesh] (Cucurbita pepo L.), Red pepper [sweet] (Capsicum annuum L.)†, Squash [flower, orange and dark yellow flesh] (Cucurbita spp.), Sweet potato [orange or dark orange] (Ipomoea batatas (L.) Lam.)†

Amaranth [greens] (Amaranthus spp.)*, American black nightshade (Solanum americanum Mill.) \{macuy, hierbamora\} ${ }^{*}$, Beet greens (Beta vulgaris L.), Broccoli (Brassica cretica Lam.)†, Chard (Beta vulgaris L.), Chipilín (Crotalaria longirostrata Hook. \& Arn.) ${ }^{\star}$, Coriander (Coriandrum sativum L.), Lettuce [dark] (Lactuca sativa L.), Mustard greens (Brassica rapa L.), Onion [stalk] (Allium cepa), Pumpkin [leaves and vine shoot] (Cucurbita pepo L.)‡, Purslane (Portulaca oleracea L.)*, Radish greens (Raphanus raphanistrum subsp. sativus (L.) Domin)‡, Squash [leaves and vine shoot] (Cucurbita spp.)

Beans [fresh pods] (Phaseolus vulgaris L.), Beets (Beta vulgaris L.), Cabbage (Brassica oleracea L.), Cauliflower (Brassica cretica Lam.)†, Chayote [fruit and vine shoot] (Sechium edule (Jacq.) Sw.)‡, Chilacayote (Cucurbita ficifolia Bouché), Cucumber (Cucumis sativus L.), Flor de izote (Yucca gigantean Lem.) ${ }^{\star}$, Flor de pito (Erythrina berteroana Urb.) ${ }^{\star}$, Green pepper [sweet] (Capsicum annuum L.)t, Maize [fresh] (Zea mays L.), Onion (Allium cepa), Pacaya (Chamaedorea tepejilote Liebm.)* Radish Raphanus raphanistrum subsp, sativus (L) Domin), Squash [unriped] (Cucurbita spp.), Tomato (Lycopersicon esculentum Mill.), Zucchini [unriped] (Cucurbita pepo L.)

Cantaloupe melon (Cucumis melo L.)t, Hog plum (Spondias purpurea L.) ${ }^{\star}$, Loquat (Eriobotrya japonica (Thunb.) Lindl.), Mango [ripe] (Mangifera indica L.), Papaya [ripe] (Carica papaya L.)

Apple (Malus pumila Mill.)t, Avocado (Persea americana Mill.), Banana (Musa $\times$ paradisiaca L.), Berries (Morus alba L. and Rubus coriifolius Liebm.) ${ }^{*}$, Cashew nut fruit (Anacardium occidentale L.), Coconut [flesh] (Cocos nucifera L.), Custard-apple (Annona reticulata L.) $)^{\star}$, Figs (Ficus carica L.), Guava (Psidium guajava) $)^{*}$, Lemon (Citrus limon (L.) Osbeck), Lime (Citrus medica (Annona reticulata L.)*, Figs (Ficus carica L.), Guava (Psidium guajava) ${ }^{\star}$, Lemon (Citrus limon (L.) Osbeck), Lime (Citrus medica (Mangifera indica L), Matasano (Casimiroa edulis La Llave), Nance (Byrsonima crassifolia (L) Kunth), Orange (Citrus sinensis (Mangifera indica L.), Matasano (Casimiroa edulis La Llave), Nance (Byrsonima crassifolia (L.) Kunth), Orange (Citrus sinen

(L.) Osbeck), Peach (Prunus persica (L.) Batsch), Pear (Pyrus communis L.) †, Pineapple (Ananas comosus (L.) Merr.),
Pomegranate (Punica granatum L.)t, Sapodella (Manilkara zapota (L.) P. Royen)*, Soursop (Annona muricata L.), Strawberry (Fragaria sp.)†, Sunza (Licania platypus (HemsI.) Fritsch), Sweet granadilla (Passiflora ligularis Juss.) ${ }^{\star}$, Tamarind (Tamarindus indica L.), Tangerine (Citrus reticulata), Watermelon (Citrullus lanatus (Thunb.) Matsum. \& Nakai)

Gizzard, Heart, Kidney, Liver, Stomach

Beef, Chicken, Duck, Goat, Pork, Rabbit, Turkey

Chicken eggs, Duck eggs

Canned fish \{tuna, sardines\}, Fresh or dried fish

eat and fish

Eggs

Eggs

10. Eggs

Flesh foods
Legumes and nuts

$$
\text { seeds }
$$

Legumes, nuts and

seeds

Milk and milk

14. Oils and fats

15. Sweets

16. Spices, condiments

NA

NA

and beverages

Cashew nut (Anacardium occidentale L.), Common beans [dry; black, red, white] (Phaseolus vulgaris L.), Lentils (Lens culinaris)

Sesamum indicum L.)t, Soya bean (Glycine max) \{texturized soya protein\}

Cheese, Milk, Ricotta

Butter, Cream, Lard, Margarine, Mayonnaise, Vegetable oils \{canola, maize, African palm, other\}

Biscuits [sweet], Candies, Cookies, Honey, Jam, Juice drinks, Sugarcane (Saccharum officinarum L.) \{panela, sugar\}, Soda, Any other sweets

Allspice (Pimienta dioica (L.) Merr)t, Annatto (Bixa orellana L.), Apazote (Dysphania ambrosioides (L.) Mosyakin \& Clemants) ${ }^{\star}$ Basil (Ocimum basilicum L., Ocimum campechianum Mill.), Broth cubes \{beef, chicken, vegetables\}, Celery (Apium graveolens L.), Chadon beni (Eryngium foetidum L.)*, Chilli [dry and fresh] (Capsicum annuum L.), Cinnamon (Cinnamomum verum J. Presl)†, Cocoa (Theobroma bicolor Humb. \& Bonpl.)t, Coffee (Coffea arabica L.), Comino (Pectis uniaristata DC. var.

holostemma A. Gray)t, Coriander (Coriandrum sativum L.), Garlic (Allium sativum L.), Hibiscus (Hibiscus sabdariffa L.), Miltomate (Physalis philadelphica Lam.) ${ }^{\star}$, Mint (Mentha $\times$ piperita L.), Oregano (Origanum vulgare L.), Parsley (Petroselinum crispum (Mill.) Fuss), Rosemary (Rosmarinus officinalis L.), Salt, Soya sauce, Tea (Camellia sinensis (L.) Kuntze) $\dagger$

IYCDDS, infant and young child dietary diversity score; IDDS, individual dietary diversity score; FANTA, Food and Nutrition Technical Assistance Project; NA, not applicable.

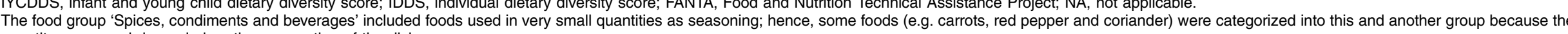

Crop name [part or condition of the crop consumed] (scientific name of crop, identified with plant specimens) ${ }^{(73,74)}\left\{\right.$ local common names for crops\}. Names are underlined when they are native to Mesoamerica ${ }^{(108,109)}$.

*Wild edible plants.

†Crops that were not identified with plant specimens, but using pictures ${ }^{(73)}$

$\ddagger$ Neglected underutilized species. 
countries (e.g. mangoes from Mexico). A substantial proportion of the sellers and consumers observed in the market were women who bought, sold and exchanged food.

Cultivated agrobiodiversity was not associated with the remoteness to the market. The price of public transportation to the market increased with the distance travelled. Consequently, a greater distance to the market was negatively correlated to the frequency of visits to it $\left(r_{(153)}^{\mathrm{s}}=-0.25, P<0.01\right)$. Hence, it was expected that participants living far from the highly food-diverse market were more likely to cultivate higher agrobiodiversity in their own food system to increase food self-sufficiency and to compensate for the infrequent visits to the market. However, agrobiodiversity richness did not increase with the distance to the market. On the contrary, Village A, the closest village to the market, was more biodiverse than further villages, probably because the former was nearer to the river used for irrigation than the latter. Likewise, Village $\mathrm{F}$, the remotest village to the market, showed the lowest cultivated agrobiodiversity, probably because the population of Village $\mathrm{F}$ was composed mainly of Ladino people; thus, their traditional ecological knowledge was

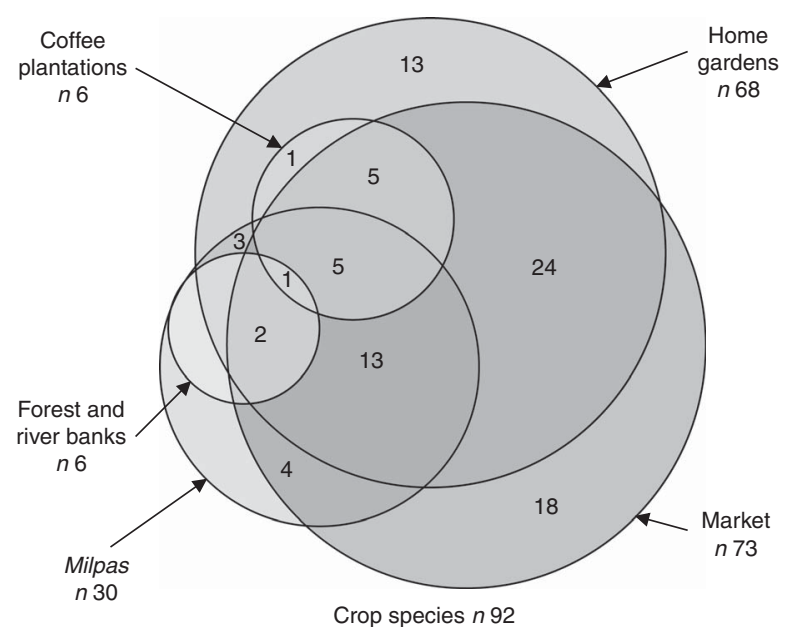

Fig. 2 Venn diagram of species found in the food systems of the sample of Mayan Achí people (154 randomly selected children aged 6-60 months and their 127 caregivers) from six rural villages in Guatemala, March-July 2016 smaller than other villages with more Mayan Achí people (e.g. Village A and Village E).

Women heading households reported the importance of cultivating greater biodiversity for food consumption and commercialization. However, there was no statistical difference between women- and men-headed households for crop species richness and NFD scores, probably due to the disproportionate sample size. Many of these women were widows from the civil war in the municipality and described agriculture as their main or sole economic activity. Similarly, women in male-headed households reported that home gardens, small animal husbandry (e.g. chickens and turkeys) and gathering of wild edible plants provided them with an extra income to complement their spouse's earnings and to cover expenses related to health and education of their children.

The NFD scores showed that higher agrobiodiversity was associated with higher nutrient availability for participants, and that each food system was specialized in providing a specific set of nutrients, such as minerals, carbohydrates and proteins (Table 3). Home gardens were good suppliers of minerals (median $\mathrm{NFD}_{\text {minerals }}=33.37$, interquartile range $=11.57$ ) because they contained a large number of species from the 'Dark-green leafy vegetables' food group. Milpas supplied considerable quantities of carbohydrates and proteins (median $\mathrm{NFD}_{\text {macronutrients }}=21.58$, interquartile range $=$ 34.84) because they contained maize and beans. But coffee plantations and tomato nurseries were mediocre suppliers of nutrients due to their low agrobiodiversity rate and the inclusion of nutrient-poor species, such as coffee. Farmers who cultivated diverse food systems could cover the nutrient requirements of their household; one food system could complement the nutrients supplied by another food system. Moreover, an increment of one species within the food systems was associated with a higher NFD by $1.52 \%\left(r^{2}=0.77, \quad P<0.01\right)$; thus, increasing cultivated agrobiodiversity could also increase the probability of covering the nutrient requirements of a farmer's household.

Participation in nutrition-sensitive programmes, ethnicity and home garden ownership were good predictors of

Table 3 Agrobiodiversity indicators of food production systems of the sample of Mayan Achí people (154 randomly selected children aged 6-60 months and their 127 caregivers) from six rural villages in Guatemala, March-July 2016

\begin{tabular}{lccccccc}
\hline & & \multicolumn{3}{c}{$\begin{array}{c}\text { Crop species richness } \\
\text { (no. of edible crop species) }\end{array}$} & & \multicolumn{2}{c}{ NFD (\%) } \\
\cline { 2 - 5 } & $\begin{array}{c}\text { Households } \\
\text { cultivating (\%) }\end{array}$ & Mean & SD & Maximum & & Median & IQR \\
\hline All & 96.7 & 14.4 & 5.4 & 30.0 & & 31.1 & 9.2 \\
Home garden & 77.5 & 12.1 & 4.6 & 28.0 & & 24.9 & 7.5 \\
Milpa & 64.9 & 3.1 & 1.4 & 6.0 & & 17.1 & 5.9 \\
Other systems & 16.2 & 1.9 & 1.2 & 5.0 & & 0.3 & 0.1 \\
Animals & 77.3 & 2.0 & 1.0 & 5.0 & & - & - \\
\hline
\end{tabular}

NFD, nutritional functional diversity; IQR, interquartile range. 
agrobiodiversity status. The participants who received local extension services, Extension Service $_{(+)}$, cultivated more crop species overall (median $=17.00$ species) than people who did not receive assistance, Extension Service $_{(-)} \quad($ median $=14.00 \quad$ species $), \quad U_{(131)}=2658.00$, $P<0 \cdot 05$. Similarly, Extension Service $_{(+)}$cultivated more crop species in their home gardens (mean $=13 \cdot 27, \mathrm{SD}=$ 5.29 species$)$ compared with Extension Service $(-)_{(\text {mean }}$ $=11.20, \mathrm{SD}=5.03$ species in home gardens), $t_{(129)}=2 \cdot 30$, $P<0.05$. In addition, results showed that crop species richness in the food systems belonging to Mayan Achí people (median $=16.00$ species) was higher than that recorded in the Ladino people' systems (median $=13.00$ species), $U_{(154)}=2129.50, \quad P<0.05$. Also, Mayan Achí people cultivated more crop species in their home gardens (mean $=12 \cdot 06, \mathrm{SD}=5.49$ species $)$ compared with Ladino people $($ mean $=9.23, \mathrm{SD}=4.37$ species $), t_{(154)}=2 \cdot 48$, $P<0.05$. Finally, participants who owned a home garden, $\mathrm{HG}_{(+)}$, cultivated more crop species overall (median = 16.00 species) than participants without a home garden, $\mathrm{HG}_{(-)}($median $=7.50$ species $), U_{(151)}=3368.00, P<0.01$; meaning that home garden ownership encourages biodiversity conservation and use for food and nutrition.

\section{Dietary diversity}

The 'Cereals' food group was the most consumed group, while animal-source foods were the least consumed food type. Foods included in the 'Cereals' group represented $28.14 \%$ of all the foods recalled by the participants. They recalled the consumption of 'Cereals' in every mealtime in the form of maize tortilla, the main food in Guatemala, or atol, a hot beverage made using nixtamalized* maize, oats, amaranth or wheat flour. In contrast, foods included in the food groups of 'Fish and seafood', 'Organ meats' and 'Flesh meats' were the least consumed by the participants: $0.05,0.13$ and $1.01 \%$, respectively. The high cost and low availability of animal-source foods caused their low consumption; participants recalled their consumption exclusively during festivities or market days. However, participants had access to other good sources of proteins, such as the food groups of 'Eggs' $3.85 \%$ of the foods recalled), 'Milk and milk products' ( $2 \cdot 37 \%$ of foods recalled) and 'Legumes, nuts and seeds' (5.29\% of foods recalled). Yet, consumption of beans was lower and less frequent than expected; it is possible that participants underestimated their consumption as the frequent consumption of beans was locally seen as a 'poor people habit'.

Micronutrient-poor and energy-dense foods were frequently consumed in high quantities by participants. The 'Sweets' food group was the second most consumed food group: $19.28 \%$ of the foods recalled were part of this group. Sugar was added to flavoured water, coffee and atol; often, participants mentioned that when sugar was lacking, they preferred not to drink any of those beverages.

\footnotetext{
* Process used to cook maize with lime
}

In addition, the food groups of 'Spices, condiments and beverages' and 'Oils and fats' respectively represented 13.22 and $2.22 \%$ of all the foods recalled. High quantities of salt and oil were added to foods when cooking to enhance the taste of meals, and in the most limited situations, 'tortilla with salt' became a meal. Ultraprocessed foods, such as pre-cooked noodles and potato chips, rich in salt and fats, represented $6.00 \%$ of the foods consumed by the participants. The high consumption of sugar, salt and fats could explain the high prevalence of stunted child-overweight mother pairs observed in the region. In addition, the frequent consumption of coffee by children could also have contributed to the high prevalence of undernutrition because it prevents the correct utilization of nutrients, such as Fe absorption ${ }^{(84)}$.

Nutrient-rich plants were neglected in the diet of the participants. Foods included in the food groups of 'Vitamin-A rich vegetables', 'Vitamin-A rich fruits' and 'Dark-green leafy vegetables' accounted for 0.67, 1.16 and $3.79 \%$ of all the foods recalled by the participants, respectively. This demonstrates a disparity between production and consumption; although American black nightshade, coriander, amaranth, radish and chayote were the top foods cultivated by participants, they did not lead the list of consumed foods (Fig. 3). Probably, selfproduced foods were not sufficient to cover the household requirements, so the participants relied on purchasing additional foods in the market, which seemed to be unhealthy foods rich in sugar, salt and fats.

Higher dietary diversity scores of the participants were positively associated with increased agrobiodiversity status. The IYCDDS was positively correlated to total crop species richness $\left(r_{(58)}^{\mathrm{s}}=+0.26, P<0.05\right)$ and home garden crop species richness $\left(r_{(58)}^{\mathrm{s}}=+0.31, P<0.05\right)$. The IDDS was also positively correlated to total crop species richness $\left(r_{(96)}^{\mathrm{s}}=+0.39, P<0.01\right)$ and home garden crop species richness $\left(r_{(96)}^{\mathrm{s}}=+0.43, P<0.01\right)$. Similarly, NFD scores were positively correlated with IDDS $\left(r_{(96)}^{\mathrm{s}}=+0 \cdot 32\right.$, $P<0 \cdot 01$ ), but were not correlated with IYCDDS. Livestock ownership was positively correlated to IYCDDS $\left(r_{(58)}^{\mathrm{s}}=+0.29, \quad P<0.05\right)$ and IDDS $\left(r_{(96)}^{\mathrm{s}}=+0.33\right.$, $P<0.01)$. Ducks, chicken and turkeys were used for eggs and meat; pigs for meat; and cows for milk and rarely for meat production.

Food self-sufficiency of participants increased along with cultivated agrobiodiversity. Self-produced foods accounted for $13.23 \%$ of participants' diets, and it was positively correlated to total crop species richness $\left(r_{(154)}^{\mathrm{s}}=+0.48, P<0.01\right)$. Also, the percentage of food items included in the diet coming from home gardens ( $8.44 \%$ on average) was positively correlated to crop species richness of home gardens $\left(r_{(154)}^{\mathrm{s}}=+0.50\right.$, $P<0.01)$. Similarly, results showed that the percentage of self-produced food items included in the diet was different between $\mathrm{HG}_{(+)}\left(\operatorname{median}_{(117)}=13.33 \%\right)$ and $\mathrm{HG}_{(-)}\left(\operatorname{median}_{(34)}=0.00 \%\right), U_{(151)}=3035.50, P<0.01$. 


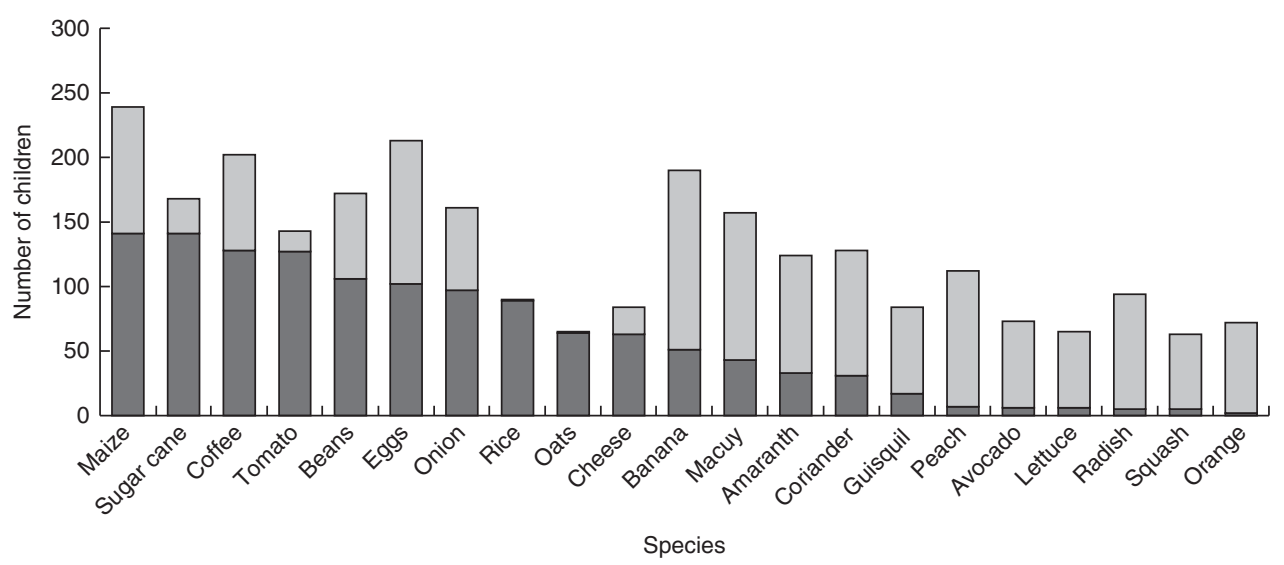

Fig. 3 Comparison of edible species consumed $(\square)$ and produced ( $\square$ ) by the sample of Mayan Achí people (154 randomly selected children aged 6-60 months and their 127 caregivers) from six rural villages in Guatemala, March-July 2016

Consumption of wild edible plants was not different between Mayan Achí and Ladino people. It was expected that Indigenous Mayan Achí people would consume wild edible plants more frequently than Ladino people because they possess more traditional ecological knowledge ${ }^{(65)}$; however, the difference between the groups was not statistically significant, $U=870 \cdot 50, P=0.486$. The proportion of consumed food items gathered in the forest or on the shore of the riverbank ( $1.94 \%$ on average) was very small in comparison to the proportion of self-produced $(13.23 \%$ on average) or purchased food items ( $60 \%)$. Many participants pointed out that wild edible plants are less frequently observed in the parcels and forest due to the increased use of 'poison', the term they used for chemical pesticides and herbicides, that 'have killed the soil'.

The correlations between maternal education and IYCDDS and IDDS were not significant. Yet, longer maternal schooling (years) was positively correlated with better socio-economic status $\left(r_{(150)}^{\mathrm{s}}=+0 \cdot 40, P<0 \cdot 01\right)$, greater food items included in the child diet $\left(r_{(150)}^{\mathrm{s}}=+0 \cdot 19\right.$, $P<0.05)$ and higher household dietary diversity scores $\left(r_{(150)}^{\mathrm{s}}=+0.21, P<0.05\right)$, a proxy of food accessibility ${ }^{(85)}$. Probably, more educated women were more likely to get a better job and higher income than less-educated women, which improved their food access. However, socioeconomic status was not directly correlated with IYCDDS nor IDDS; probably, the extra income was used to purchase foods other than nutrient-rich ones, such as sugar or ultra-processed foods. The frequency of visits to market was positively correlated to items included in the daily diet $\left(r_{(153)}^{\mathrm{s}}=+0.19, P<0.05\right)$, household dietary diversity scores $\left(r_{(153)}^{\mathrm{s}}=+0.22, \quad P<0.01\right)$ and IDDS $\left(r_{(96)}^{\mathrm{s}}=+0.22, P<0.05\right)$.

\section{Child anthropometric status}

Child undernutrition was extensive in the municipality. Stunting was the most prevalent malnutrition issue (60.40\% of participant children) followed by underweight (19.50\%) and wasting (1.30\%). No statistically significant correlation was found between child anthropometric status and dietary diversity scores, as expected, but there were other variables (i.e. child morbidity, socio-economic status, and maternal education and age) with a stronger association to child anthropometric status than diet.

Child morbidity was negatively associated with child anthropometric status. Children who had suffered from infections the month prior to the interview were more likely to have lower weight than healthy children. WAZ was statistically smaller in sick children (mean $=-1.40$, $\mathrm{SD}=0.95)$ than in healthy children (mean $=-0.86$, $\mathrm{SD}=0.96), t_{(83)}=2.45, P<0.05$; and WHZ was statistically smaller in sick children (mean $=-0 \cdot 17, \mathrm{SD}=1 \cdot 13$ ) than in healthy children (mean $=0.33, \mathrm{SD}=0.86$ ), $t_{(83)}=2.06, P<0.05$.

Socio-economic status might affect anthropometric status through WASH conditions. Agrobiodiversity status and dietary diversity scores were not correlated to anthropometric status nor socio-economic status. But, better socio-economic status was positively correlated to greater HAZ $\left(r_{(154)}^{\mathrm{P}}=+0 \cdot 17, P<0.05\right)$ and greater WAZ $\left(r_{(154)}^{\mathrm{p}}=+0 \cdot 22, P<0 \cdot 01\right)$. Probably, socio-economic status was associated with nutrition through pathways other than diet. In fact, socio-economic status reflected the housing conditions that could impact child health status, such as regular and drinking-water availability, management of residues and sanitation condition. Therefore, we speculate that socio-economic status determines the risk of sickness and thereby the anthropometric status of children.

Maternal education, age and number of children were associated with the children's anthropometric status. Longer maternal schooling was positively correlated with greater $\mathrm{HAZ}\left(r_{(150)}^{\mathrm{p}}=+0.20, P<0.05\right)$ and greater maternal age was correlated with greater WAZ $\left(r_{(149)}^{\mathrm{p}}=+0 \cdot 20, P<0 \cdot 05\right)$. Yet, age can be a confounding variable because mother's age was positively associated to the number of people living in the house $\left(r_{(146)}^{\mathrm{s}}=+0 \cdot 44\right.$, $P<0 \cdot 01$ ), which in turn could reduce availability of and access to resources, such as food. 


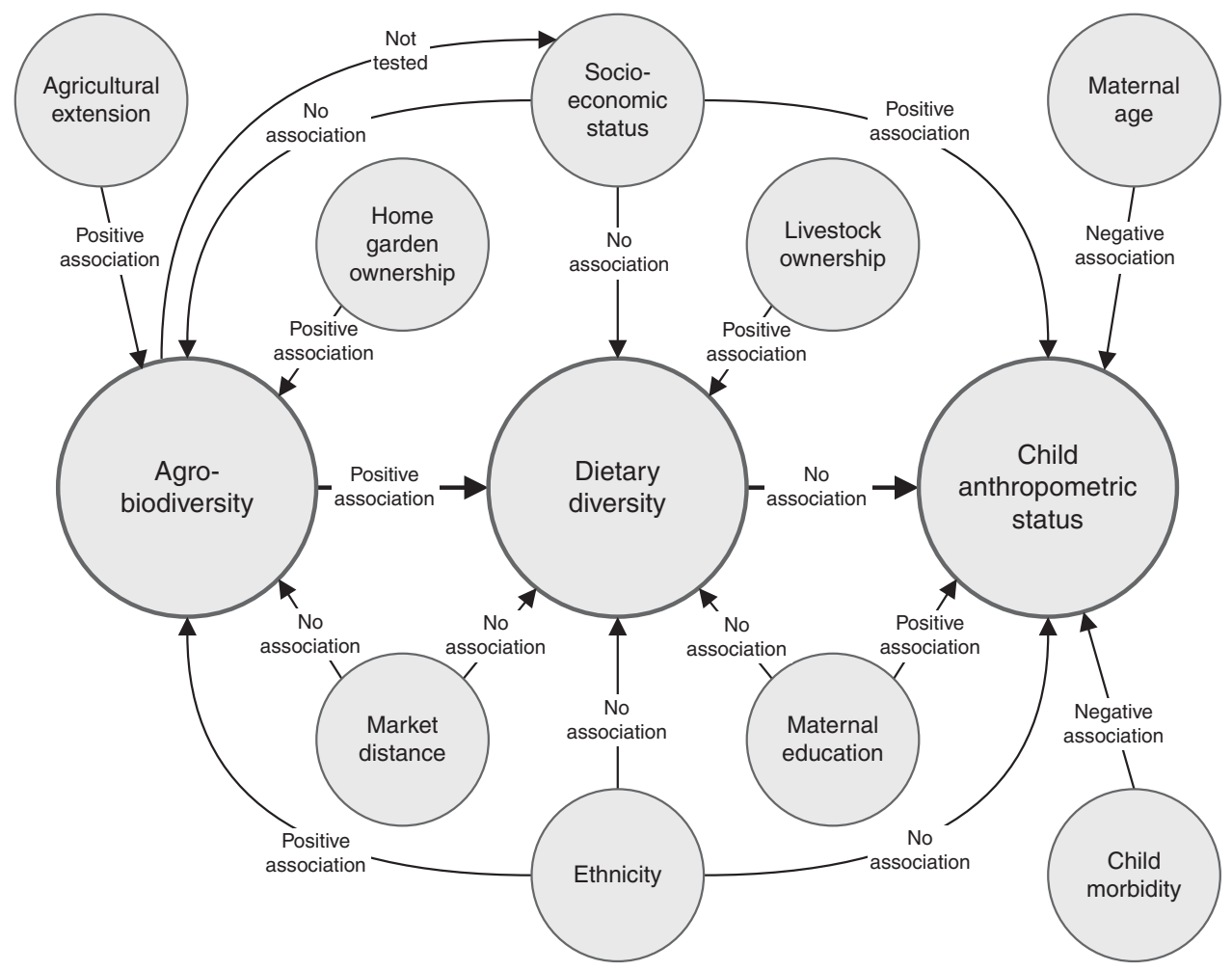

Fig. 4 Graphical summary of results: impact of agrobiodiversity on child nutrition through dietary diversification among the sample of Mayan Achí people (154 randomly selected children aged 6-60 months and their 127 caregivers) from six rural villages in Guatemala, March-July 2016

Figure 4 presents a graphic summarizing the present results on the impact of agrobiodiversity on child nutrition through dietary diversification.

\section{Discussion}

Interventions focused on conservation and sustainable use of agrobiodiversity have the potential to improve public health nutrition by increasing dietary diversity. In the present and other studies, cultivated agrobiodiversity (i.e. crop species richness and livestock ownership) was associated with higher dietary quality (i.e. dietary diversity scores $)^{(35,40-44,48,86)}$. The farmers cultivating more agrobiodiversity consumed more micronutrient-rich food groups (i.e 'Dark-green leafy vegetables' and 'Vitamin A-rich vegetables and fruits' $)^{(40)}$ and had better dietary diversity scores ${ }^{(35,46,87)}$ than farmers cultivating less agrobiodiversity. Agrobiodiverse food systems can supply nutritious foods and diversify diets, and, in turn, improve nutrition.

In fact, higher cultivated agrobiodiversity can supply more variety and increased availability of nutrients (i.e. NFD scores). We found that the more species farmers cultivated, the more chances nutrient variety and availability would increase. This was especially true when local wild edible plants were cultivated by farmers because these species are good sources of Fe, Ca, vitamin $\mathrm{C}$ and vitamin $\mathrm{A}^{(77)}$. Our results are consistent with studies in Malawi $^{(76)}$, Kenya ${ }^{(23)}$ and in the Millennium Villages Project in Africa ${ }^{(88)}$ where higher crop species richness was correlated with higher NFD scores, and, thus, with more nutritional diverse food systems.

Likewise, food self-sufficiency can be improved by cultivated agrobiodiversity. The farmers producing more food types consumed a higher proportion of self-produced nutritious foods ${ }^{(35,36,46,89)}$. However, they consumed more micronutrient-poor, energy-dense food groups (i.e. 'Cereals' and 'Sweets' and 'Oils and fats') than micronutrient-rich food groups. The production of micronutrient-rich foods was probably not sufficient to cover the participants' nutritional requirements, and their price was higher than the price of unhealthy foods. Consequently, participants preferred to buy unhealthy foods to cover their requirements and, on some occasions, to sell their self-produced nutritious foods. Therefore, yields of nutritious foods should be increased and sustained over time to improve food self-sufficiency and dietary diversity.

For the reasons listed above, we support the idea that agrobiodiverse agriculture can provide higher nutritional benefits to farmers' households than specialized agriculture. The excessive consumption of ultra-processed foods makes us think that interventions based on specialization for improving agricultural revenues, supported by some scholars ${ }^{(42,43)}$, would not increase consumption of healthy foods. 
Our view is that specialization will accelerate the dietary transition towards processed foods that is already happening in the region ${ }^{(34)}$ and thus worsen the incidence of dietrelated diseases. Enhancing nutritional education ${ }^{(40,89-92)}$, empowering women ${ }^{(46,55,56,87)}$ and increasing yields of vegetables and fruits over time could motivate cultivation and consumption of nutritious foods.

However, agrobiodiversity cannot improve nutrition if food utilization is hampered by morbidity. Food utilization, the way the body makes the most of dietary nutrients, can be enhanced through improving health status, household characteristics and WASH conditions. In the present study and others, the association between dietary diversity scores and child anthropometric status was not significant ${ }^{(39,88,93,94)}$ probably because children were frequently sick; we found a strong correlation between child morbidity and undernutrition ${ }^{(51,57,95)}$. Infections could compromise the integrity of the digestive and immunological system, affecting the absorption and proper use of consumed nutrients ${ }^{(96)}$. Poor WASH and housing conditions, reflected in the socio-economic status, could increase the risk of infections in children and thus child undernutrition.

Other underlying factors, such as poverty and low education, can also affect food utilization and prevent agrobiodiversity from improving nutrition. In the present study, poor family planning ${ }^{(97)}$ and the number of household members ${ }^{(42)}$ were negatively associated with child anthropometric status, probably because they compromised sanitation conditions and food availability. Other studies carried out in Guatemala have also shown that low maternal education and poor housing quality ${ }^{(98)}$, frequent parasitic infections $^{(97)}$, Mayan ethnicity ${ }^{(99)}$ and early age at first parturition $^{(100)}$ negatively affected child anthropometric status. In Guatemala, poverty and undernourishment are persistent problems within the ethnic Mayan people because they are severely discriminated against and have limited access to jobs and public services (e.g. roads, water, electricity, health care and education $)^{(101,102)}$.

Finally, agrobiodiverse agriculture can be translated into improved nutrition only if the nutritious foods produced are consumed by growing children and women of reproductive age. Especially children in their first $1000 \mathrm{~d}$ of life and pregnant or lactating women require more nutrients than people in another life stage. However, in some regions, such as Guatemala, food is preferably allocated to older boys, men and elders ${ }^{(33)}$. Nutritional education and empowerment of women can also help to overcome the poor understanding and awareness of undernutrition ${ }^{(103,104)}$ and the unequal allocation of food within members of the household ${ }^{(33,104,105)}$.

The present study used a cross-sectional design, so it could picture the status of agrobiodiversity and its impact on dietary diversity at a particular moment. Future studies would benefit from adopting a longitudinal design that would better describe the changes in food production systems due seasonal variations (e.g. rainfall and climate changes), fluctuations in food prices and availability at the market, and the changes in the height and weight of children.

\section{Conclusion}

Agricultural interventions that increase agrobiodiversity of both crops and livestock, for food production, are promising alternatives diversifying diets and increasing nutrient intakes. However, such interventions need to be accompanied with substantial improvements in WASH and housing conditions to reduce child morbidity and thus increase food utilization. In addition, these interventions need to include an important level of focus on family planning, nutritional education, and Indigenous and women's empowerment. We propose that agricultural interventions including all these elements could improve child nutrition through dietary diversification.

\section{Acknowledgements}

Acknowledgements: The authors are grateful for the help and guidance provided by Juan Jose Castillo Mont and David Elías Mendieta Jiménez from the herbarium of University of San Carlos of Guatemala and Stephen Onakuse from University College Cork. Also, special thanks are extended to the Association $X$ for its kind support, especially Rosalia, Sarah and the team of nutrition extensionists. The authors thank the two anonymous reviewers and Dr Brian W.W. Grout whose comments helped improve and clarify this manuscript. Financial support: This study was supported by the National Council of Science and Technology of Mexico (CONACYT) (scholarship number 383742). CONACYT had no role in the design, analysis or writing of this article. Conflict of interests: None. Authorship: D.V.L.-G. formulated the research question, designed the study, carried out the fieldwork and collected the plant specimens, analysed the gathered data and wrote the manuscript. M.S. was involved in the research question formulation, study design, taxonomic identification and manuscript review. All authors read and approved the final manuscript. Ethics of buman subject participation: Verbal consent was witnessed and formally recorded.

\section{References}

1. Food and Agriculture Organization of the United Nations, International Fund for Agricultural Development et al. (2017) The State of Food Security and Nutrition in the World 2017. Building Resislience for Peace and Food Security. Rome: FAO.

2. Black RE, Victora CG, Walker SP et al. (2013) Maternal and child undernutrition and overweight in low-income and middle-income countries. Lancet 382, 427-451.

3. Development Initiatives Poverty Research Ltd (2017) Global Nutrition Report 2017. Nutrition Country Profile: 
Guatemala. https://www.globalnutritionreport.org/files/ 2017/12/gnr17-Guatemala.pdf (accessed March 2018).

4. Borlaug N (2007) Feeding a hungry world. Science 318, 359.

5. The World Bank (2008) World Development Report 2008: Agriculture for Development. Washington, DC: World Bank.

6. Dwivedi SL, Lammerts van Bueren ET, Ceccarelli S et al. (2017) Diversifying food systems in the pursuit of sustainable food production and healthy diets. Trends Plant Sci 22, 842-856.

7. Pingali PL (2012) Green revolution: impacts, limits, and the path ahead. Proc Natl Acad Sci U S A 109, 12302-12308.

8. Khoury CK, Bjorkman AD, Dempewolf $\mathrm{H}$ et al. (2014) Increasing homogeneity in global food supplies and the implications for food security. Proc Natl Acad Sci U S A 111, 4001-4006.

9. Sunderland TCH (2011) Food security: why is biodiversity important? Int Forest Rev 13, 265-274.

10. Pingali P (2015) Agricultural policy and nutrition outcomes - getting beyond the preoccupation with staple grains. Food Secur 7, 583-591.

11. Tuxill J (1999) Appreciating the benefits of plant biodiversity. In State of the World, 1999, pp. 96-114. Washington, DC: Worldwatch Institute.

12. Phalan B, Bertzky M, Butchart SHM et al. (2013) Crop expansion and conservation priorities in tropical countries. PLOS One 8, e 51759.

13. Burchi F, Fanzo J \& Frison E (2011) The role of food and nutrition system approaches in tackling hidden hunger. Int J Environ Res Public Health 8, 358-373.

14. Kataki PKK (2014) Shifts in cropping system and its effect on human nutrition: case study from India. J Crop Prod $\mathbf{6}$, 119-144.

15. Thrupp LA (2000) Linking agricultural biodiversity and food security: the valuable role of agrobiodiversity for sustainable agriculture. Int Aff 76, 265-281.

16. Hunter D, Burlingame B \& Remans R (2015) Biodiversity and nutrition. In Connecting Global Priorities: Biodiversity and Human Health, A State of Knowledge Review, pp. 97-129 [C Romanelli, D Cooper, D Campbell-Lendrum et al., editors]. Geneva and Montreal: WHO and Secretariat of the Convention on Biological Diversity.

17. Heywood VH (2013) Overview of agricultural biodiversity and its contribution to nutrition and health. In Diversifying Food and Diets: Using Agricultural Biodiversity to Improve Nutrition and Health, pp. 35-67 [J Fanzo, D Hunter, T Borelli et al., editors]. Rome: Earthscan.

18. Frison E, Smith I, Johns T et al. (2006) Agricultural biodiversity, nutrition and health: making a difference to hunger and nutrition in the developing world. Food Nutr Bull 27, 167-179.

19. Kremen C, Iles A \& Bacon C (2012) Diversified farming systems: an agroecological, systems-based alternative to modern industrial agriculture. Ecol Soc 17, 44.

20. Helen Keller International (2010) Homestead food production model contributes to improved household food security, nutrition and female empowerment experience from scaling-up programs in Asia (Bangladesh, Cambodia, Nepal and Philippines). HKI Nutrition Bulletin $\mathbf{8}$, issue 1. http://knowledge.hki.org/publications/APRO\% 20Bulletin_HFP\%20and\%20Food\%20Security.pdf (accessed March 2018).

21. Grivetti LE \& Ogle BM (2000) Value of traditional foods in meeting macro- and micronutrient needs: the wild plant connection. Nutr Res Rev 13, 31-46.

22. Cernansk R (2015) Super vegetables. Nature 522, 146-148.

23. DeClerck FAJ, Fanzo J, Palm C et al. (2011) Ecological approaches to human nutrition. Food Nutr Bull 32, Suppl. 1, S41-S50.

24. Vinceti B, Eyzaguirre PB \& Johns T (2008) The nutrition role of forest plant foods for rural communities. In Human
Health and Forests: A Global Overview of Issues, Practice and Policy, pp. 63-96 [CJP Colfer, editor]. London: Earthscan.

25. Cardinale BJ, Duffy JE, Gonzalez A et al. (2012) Biodiversity loss and its impact on humanity. Nature $\mathbf{4 8 6}$, 57-67.

26. Kremen C \& Miles A (2012) Ecosystem services in biologically diversified versus conventional farming systems, benefits, externalities and trade offs. Ecol Soc 17, 40.

27. Johns T \& Eyzaguirre PB (2007) Biofortification, biodiversity and diet: a search for complementary applications against poverty and malnutrition. Food Policy 32, 1-24.

28. Chivenge P, Mabhaudhi T, Modi A et al. (2015) The potential role of neglected and underutilised crop species as future crops under water scarce conditions in Sub-Saharan Africa. Int J Environ Res Public Health 12, 5685-5711.

29. Food and Agriculture Organization of the United Nations (2008) Climate Change and Biodiversity for Food and Agriculture. Rome: FAO.

30. Powell B, Thilsted SH, Ickowitz A et al. (2015) Improving diets with wild and cultivated biodiversity from across the landscape. Food Secur 7, 535-554.

31. Masset E, Haddad L, Cornelius A et al. (2012) Effectiveness of agricultural interventions that aim to improve nutritional status of children: systematic review. BMJ 344, d8222.

32. Ruel MT (2001) Can Food-Based Strategies Help Reduce Vitamin A and Iron Deficiencies? A Review of Recent Evidence. Food Policy Review no. 5. Washington, DC: International Food Policy Research Institute.

33. Webb Girard A, Self JL, McAuliffe C et al. (2012) The effects of household food production strategies on the health and nutrition outcomes of women and young children: a systematic review. Paediatr Perinat Epidemiol 26, Suppl. 1, 205-222.

34. Dewey KG (1981) Nutritional consequences of the transformation from subsistence to commercial agriculture in Tabasco, Mexico. Hum Ecol 9, 151-187.

35. Jones AD (2017) On-farm crop species richness is associated with household diet diversity and quality in subsistence- and market-oriented farming households in Malawi. J Nutr 147, 86-96.

36. Oyarzun PJ, Mary Borja R, Sherwood S et al. (2013) Making sense of agrobiodiversity, diet, and intensification of smallholder family farming in the Highland Andes of Ecuador. Ecol Food Nutr 52, 515-541.

37. Yeudall F, Sebastian R, Cole DC et al. (2007) Food and nutritional security of children of urban farmers in Kampala, Uganda. Food Nutr Bull 28, 237-246.

38. M'Kaibi FK, Steyn NP, Ochola S et al. (2015) Effects of agricultural biodiversity and seasonal rain on dietary adequacy and household food security in rural areas of Kenya. BMC Public Health 15, 422.

39. Vanek SJ, Jones AD \& Drinkwater LE (2016) Coupling of soil regeneration, food security, and nutrition outcomes in Andean subsistence agroecosystems. Food Secur 8, 727-742.

40. Jones AD, Shrinivas A \& Bezner-Kerr R (2014) Farm production diversity is associated with greater household dietary diversity in Malawi: findings from nationally representative data. Food Policy 46, 1-12.

41. Kumar N, Harris J \& Rawat R (2015) If they grow it, will they eat and grow? Evidence from Zambia on agricultural diversity and child undernutrition. J Dev Stud 51, 1060-1077.

42. Koppmair S, Kassie M \& Qaim M (2017) Farm production, market access and dietary diversity in Malawi. Public Health Nutr 20, 325-335.

43. Sibhatu KT, Krishna VV \& Qaim M (2015) Production diversity and dietary diversity in smallholder farm households. Proc Natl Acad Sci U S A 112, 10657-10662.

44. Ekesa B, Walingo M \& Abukutsa-Onyango M (2008) Influence of agricultural biodiversity on dietary diversity of 
preschool children in Matungu division, western Kenya. Afr J Food Agric Nutr Dev 8, 390-404.

45. Dillon A, McGee K \& Oseni G (2015) Agricultural production, dietary diversity and climate variability. J Dev Stud 51, 976-995.

46. Olney DK, Talukder A, Iannotti LL et al. (2009) Assessing impact and impact pathways of a homestead food production program on household and child nutrition in Cambodia. Food Nutr Bull 30, 355-369.

47. Raneri JE, Kennedy G \& Lachat C (2016) The role of agrobiodiversity in local food systems and diets: a case study from Vietnam. Poster presented at Royal Academy for Overseas Sciences - Young Researchers Day, Brussels, Belgium, 13 December 2016.

48. Bellon MR, Ntandou-Bouzitou GD \& Caracciolo F (2016) On-farm diversity and market participation are positively associated with dietary diversity of rural mothers in southern Benin, west Africa. PLoS One 11, e0162535.

49. Talukder A, Haselow N, Osei AK et al. (2010) Homestead food production model contributes to improved household food security and nutrition status of young children and women in poor populations lessons learned from scaling-up programs in Asia (Bangladesh, Cambodia, Nepal and Philippines). Field Actions Sci Rep, special issue, http://factsreports.revues.org/404.

50. Faber M, Venter SL \& Benadé AJS (2002) Increased vitamin A intake in children aged $2-5$ years through targeted home-gardens in a rural South African community. Public Health Nutr 5, 11-16.

51. Kidala D, Greiner T \& Gebre-Medhin M (2000) Five-year follow-up of a food-based vitamin a intervention in Tanzania. Public Health Nutr 3, 425-431.

52. Roche M, Creed-Kanashiro H, Tuesta I et al. (2008) Traditional food diversity predicts dietary quality for the Awajún in the Peruvian Amazon. Public Health Nutr 11, $457-465$.

53. Sibhatu KT, Krishna VV \& Qaim M (2015) Reply to Berti: relationship between production and consumption diversity remains small also with modified diversity measures. Proc Natl Acad Sci U S A 112, E5657.

54. Hoddinott J, Headey D \& Dereje M (2015) Cows, missing milk markets, and nutrition in rural Ethiopia. J Dev Stud 51, 958-975.

55. Jones AD, Cruz Agudo Y, Galway L et al. (2012) Heavy agricultural workloads and low crop diversity are strong barriers to improving child feeding practices in the Bolivian Andes. Soc Sci Med 75, 1673-1684.

56. Malapit HJL, Kadiyala S, Quisumbing AR et al. (2015) Women's empowerment mitigates the negative effects of low production diversity on maternal and child nutrition in Nepal. J Dev Stud 51, 1097-1123.

57. Azzarri C, Zezza A, Haile B et al. (2015) Does livestock ownership affect animal source foods consumption and child nutritional status? Evidence from rural Uganda. J Dev Stud 51, 1034-1059.

58. Powell B, Ouarghidi A, Johns T et al. (2014) Wild leafy vegetable use and knowledge across multiple sites in Morocco: a case study for transmission of local knowledge? J Ethnobiol Ethnomed 10, 34.

59. Ogle BM, Hung PH \& Tuyet HT (2001) Significance of wild vegetables in micronutrient intakes of women in vietnam: an analysis of food variety. Asia Pac J Clin Nutr 10, 21-30.

60. Termote C, Bwama Meyi M, Dhed'a Djailo B et al. (2012) A biodiverse rich environment does not contribute to a better diet: a case study from DR Congo. PLoS One 7, e30533.

61. Ogle BM, Xuan Dung NN, Thanh Do T et al. (2001) The contribution of wild vegetables to micronutrient intakes among women: an example from the Mekong Delta, Vietnam. Ecol Food Nutr 40, 159-184.
62. Boedecker J, Termote C, Assogbadjo AE et al. (2014) Dietary contribution of wild edible plants to women's diets in the buffer zone around the Lama forest, Benin - an underutilized potential. Food Secur 6, 833-849.

63. Jones AD \& Ejeta G (2016) A new global agenda for nutrition and health: the importance of agriculture and food systems. Bull World Health Organ 94, 228-229.

64. Ericksen PJ (2008) Conceptualizing food systems for global environmental change research. Glob Environ Chang 18, 234-245.

65. Turreira-García N, Theilade I, Meilby H et al. (2015) Wild edible plant knowledge, distribution and transmission: a case study of the Achí Mayans of Guatemala. J Ethnobiol Ethnomed 11, 52.

66. Ministerio de Agricultura, Ganadería y Alimentación (2006) Mapa de Zonas de Vida de Holdridge de La República de Guatemala. Guatemala: MAGA.

67. Ministerio de Agricultura, Ganadería y Alimentación (2006) Mapa de Taxonomia de Suelos Y Capacidad de Uso de La Tierra de La República de Guatemala. Guatemala: MAGA.

68. National Statistical Service (2018) Sample size calculator. http://www.nss.gov.au/nss/home.nsf/pages/Sample+size +calculator (accessed March 2018)

69. Arevalo-Jucub MB (2009) Experiencias en el programa de seguridad alimentaria y nutritional en comunidades rurales de Rabinal y Cubulco, departamento de Baja Verapaz. Agronomic Engineering Thesis, University of San Carlos de Guatemala.

70. Méndez A (1970) Método para medir la situación sociocultural de las familias rurales centroamericanas y su aplicación a los programas de salud. Arch Latinoam Nutr 20, 281-291.

71. Arroyave G (2010) Investigation of the nutrition problems of central America and Panama. Food Nutr Bull 31, 9-15.

72. International Society of Ethnobiology (2006) International Society of Ethnobiology Code of Ethics (with 2008 additions). http://www.ethnobiology.net/what-we-do/ core-programs/ise-ethics-program/code-of-ethics/code-inenglish/ (accessed March 2018).

73. Standley PC, Williams LO \& Steyermark JA (1975) Flora of Guatemala. Fieldiana Bot 24, Pt 2.

74. The Plant List (2013) Version 1.1. http://www.theplantlist. org/ (accessed March 2018).

75. Petchey OL \& Gaston KJ (2002) Functional diversity (FD), species richness and community composition. Ecol Lett $\mathbf{5}$, 402-411.

76. Luckett BG, Declerck FA, Fanzo J et al. (2015) Application of the nutrition functional diversity indicator to assess food system contributions to dietary diversity and sustainable diets of Malawian households. Public Health Nutr 18, 2479-2487.

77. Instituto de Nutrición de Centro América y Panamá \& Organización Panamericana de la Salud (2007) Tabla de Composicion de Alimentos Para Centroamerica, 2nd ed. (M Menchú and H Mendez, editors). Guatemala: INCAP/OPS.

78. US Department of Agriculture (2016) USDA Food Composition Databases. https://ndb.nal.usda.gov/ndb/ (accessed March 2018).

79. National Research Council (2000) Dietary Reference Intakes: Applications in Dietary Assessment. Washington, DC: National Academies Press.

80. Swindale A \& Bilinsky P (2006) Housebold Dietary Diversity Score (HDDS) for Measurement of Housebold Food Access: Indicator Guide. Washington, DC: Food and Nutrition Technical Assistance III Project (FANTA), FHI 360.

81. World Health Organization (2010) Indicators for Assessing Infant and Young Child Feeding Practices. Part 2: Measurement. Geneva: WHO. 
82. Food and Agriculture Organization of the United Nations (2008) Guidelines for Measuring Housebold and Individual Dietary Diversity. Rome: FAO.

83. World Health Organization (2011) WHO Anthro (version 3.2.2, January 2011) and macros. http://www.who.int/ childgrowth/software/en/ (accessed March 2018).

84. Dewey G, Romero-Abal ME, de Sarrano JQ et al. (1997) Effects of discontinuing coffee intake on iron status of iron-deficient Guatemalan toddlers: a randomized intervention study. Am J Clin Nutr 66, 168-176.

85. Cafiero C, Melgar-Quiñonez HR, Ballard TJ et al. (2014) Validity and reliability of food security measures. Ann NY Acad Sci 1331, 230-248.

86. Pellegrini L \& Tasciotti L (2014) Crop diversification, dietary diversity and agricultural income: empirical evidence from eight developing countries. Can J Dev Stud 35, 211-227.

87. Keding GB, Msuya JM, Maass BL et al. (2012) Relating dietary diversity and food variety scores to vegetable production and socio-economic status of women in rural Tanzania. Food Secur 4, 129-140.

88. Remans R, Flynn DF, DeClerck F et al. (2011) Assessing nutritional diversity of cropping systems in African villages. PLoS One 6, e21235.

89. Faber M, Phungula MA, Venter SL et al. (2002) Home gardens focusing on the production of yellow and dark green leafy vegetables increase the serum retinol concentrations of 2-5-year-old children in South Africa. Am J Clin Nutr 76, 1048-1054.

90. Kaufer L, Englberger L, Cue R et al. (2010) Evaluation of a 'traditional food for health' intervention in Pohnpei, Federated States of Micronesia. Pac Health Dialog 16, 61-73.

91. Kennedy A, Kadiyala S, Daniel R et al. (2017) Homestead food production and child anemia in Burkina Faso: the mediating roles of mother's knowledge and production of micronutrient-rich fruits and vegetables. FASEB J 31, 786.45 .

92. Brauw A, de Eozenou P \& Moursi M (2015) Programme participation intensity and children's nutritional status: evidence from a randomised control trial in Mozambique. J Dev Stud 51, 996-1015.

93. Schipani S, van der Haar F, Sinawat S et al. (2002) Dietary intake and nutritional status of young children in families practicing mixed home gardening in northeast Thailand. Food Nutr Bull 23, 175-180.

94. Makhotla L \& Hendriks S (2004) Do home gardens improve the nutrition of rural pre-schoolers in Lesotho? Dev South Afr 21, 575-581.

95. English R \& Badcock J (1998) A community nutrition project in Viet Nam: effects on child morbidity. Food Nutr Agric 22, 15-21.

96. Humphrey JH, Jones AD, Manges A et al. (2015) The Sanitation Hygiene Infant Nutrition Efficacy (SHINE) trial: rationale, design, and methods. Clin Infect Dis 61, Suppl. 7, S685-S702.

97. Sereebutra P, Solomons N, Aliyu MH et al. (2006) Sociodemographic and environmental predictors of childhood stunting in rural Guatemala. Nutr Res 26, 65-70.

98. Pebley AR \& Goldman N (1995) Social inequality and children's growth in Guatemala. Health Transit Rev $\mathbf{5}, 1-20$.

99. Reurings M, Vossenaar M, Doak CM et al. (2013) Stunting rates in infants and toddlers born in metropolitan Quetzaltenango, Guatemala. Nutrition 29, 655-660.

100. Martorell R \& Young MF (2012) Patterns of stunting and wasting: potential explanatory factors. Adv Nutr $\mathbf{3}$, $227-233$.

101. Loewenberg S (2009) Guatemala's malnutrition crisis. Lancet 374, 187-189.

102. Solomons NW, Vossenaar M, Chomat A-M et al. (2015) Stunting at birth: recognition of early-life linear growth failure in the western highlands of Guatemala. Public Health Nutr 18, 1737-1745.

103. Chary A, Messmer S, Sorenson E et al. (2013) The normalization of childhood disease: an ethnographic study of child malnutrition in rural Guatemala. Hum Organ 72, 87-97.

104. Brown K, Henretty N, Chary A et al. (2016) Mixed-methods study identifies key strategies for improving infant and young child feeding practices in a highly stunted rural indigenous population in Guatemala. Matern Child Nutr 12, 262-277.

105. Wehr H, Chary A, Webb MF et al. (2014) Implications of gender and household roles in Indigenous Maya communities in Guatemala for child nutrition interventions. Int J Indig Health 10, 99-112.

106. UNICEF (1998) The State of the World's Children. New York: Oxford University Press.

107. World Health Organization (2008) Indicators for Assessing Infant and Young Child Feeding Practices. Part 1: Definitions, p. 19. Geneva: WHO.

108. Standley PC \& Steyermark JA (1949) Flora de Guatemala. vol. 24. Chicago, IL: Chicago Natural History Museum.

109. CABI (2017) Invasive Species Compendium. http://www. cabi.org/isc (accessed August 2017).

110. Food and Agriculture Organization of the United Nations (1999) Background Papers - Agricultural Biodiversity, FAO/Netherlands Conference on the Multifunctional Character of Agriculture and Land Conference. Background Paper 1: Agricultural Biodiversity. http://www.fao. org/mfcal/pdf/bp_1_agb.pdf (accessed March 2018).

111. Cruz-Garcia GS \& Struik PC (2015) Spatial and seasonal diversity of wild food plants in home gardens of northeast Thailand. Econ Bot 69, 99-113. 